\title{
EVALUASI PROGRAM TRIDARMA PERGURUAN TINGGI DALAM PENGEMBANGAN SUMBERDAYA MANUSIA MENUJU WORLD CLASS UNIVERSITY PADA INSTITUT AGAMA ISLAM NEGERI BENGKULU
}

\author{
Khairiah \\ Dosen Pascasarjana IAIN Bengkulu \\ Khairiah@iainbengkulu.ac.id
}

\begin{abstract}
The purpose of this study was to evaluate the role of tridarma Perguruan Tinggi at the state Islamic Institute (IAIN) Bengkulu in developing human resources towards world-class universities, evaluation focused on four aspects, namely background, planning, implementation and products program. The method used in this study is a qualitative approach to program evaluation design. The component that becomes the benchmark of program evaluation is the context input process and product (CIPP) model, data collection through in-depth interview and documentation studies, with Bengkulu lecturers, staff, and management. The steps are; data reduction, data display, and drawing conclusions. The results of this study conclude that the role of Tridarma of Higher education is ini accordance with the background of the program seen from the aspects of needs, problems and objectives. This program is supported by a fairly good plan that is shown by aspects of human resources, budget, facilities and curriculum. The program has been implemented quite well indicated by timeliness, teaching methods, monitoring and evaluation, human resources development, recruitment, and sevice aspect. In general, this program shows quite good results as indicated by perceptive, reliable, skilled, and professional aspects of support to realize world-class universities. Therefore, it is especially improvements in the planning and implementation stages.
\end{abstract}

Keywords: Evaluation program, Tridarma College, World Class University

\begin{abstract}
Abstrak: Tujuan penelitian ini adalah untuk mengevaluasi program peran Tridarma Peguruan Tinggi pada Institut Agama Islam Negeri (IAIN) Bengkulu dalam pengembangan sumberdaya manusia menuju universitas kelas dunia. evaluasi difokuskan pada empat aspek, yaitu latar belakang, perencanaan, implementasi dan produk program. Metode yang digunakan dalam penelitian ini pendekatan kualitatif dengan desain evaluasi program. Komponen yang menjadi tolak ukur evaluasi program adalah model context, input, process dan product (CIPP). Pengumpulan data melalui wawancara mendalam dan studi dokumentasi, dengan dosen, staf, dan pihak manajemen penyelenggaraan tridarma perguruan tinggi, civitas akademika IAIN Bengkulu.Dengantigalangkah yaitu; reduksi data, tampilan data, dan tahap menggambar kesimpulan. Hasil penelitian ini menyimpulkan bahwa peran tridarma perguruan tinggi sesuai dengan latar belakang program yang dilihat dari aspek kebutuhan, masalah dan tujuan. program ini didukung dengan rencana yang cukup baik yang ditunjukkan oleh aspek sumberdaya manusia, anggaran, fasilitas dan kurikulum. program telah diimplementasikan dengan cukup baik ditunjukkan oleh ketepatan waktu,metode pengajaran, monitoring dan evaluasi, pengembangan sumberdaya manusia, rekrutmen, dan aspek layanan. secara umum, program ini menunjukkan hasil yang cukup baik yang ditunjukkan oleh aspek perseptif, andal, terampil, dan professional dukungan untuk mewujudkan universitas kelas dunia. Oleh karena itu, disarankan program ini perlu dilanjutkan terutama perbaikan dalam tahap perencanaan dan implementasi.
\end{abstract}

Kata Kunci: Program Evaluasi, Tridarma Perguruan Tinggi, World Class University.

58 NUANSA Vol. XII, No. 1, Juni 2019 
Khairiah | Evaluasi Program Tridarma Perguruan Tinggi

\section{Pendahuluan}

Peran tridarma perguruan tinggi penting dalam upaya pengembangan sumberdaya manusia di era globalisasi. Sumberdaya manusia(SDM) dan lingkungan stratejik yang tidak mendukung dapat menurunkan kinerja dan daya saing organisasi. Sebaliknya dengan memanfaatkan segala potensi yang tersedia dan menggunakan peluang pada momen yang tepat organisasi dapat eksis dan melesat maju di era globalisasi ini. Abad 21 merupakan abad mutu, ${ }^{1}$ SDM yang handal mampu mengelola secara efektif berbagai kelemahan, ancaman sekaligus kekuatan dan peluang.

Persipan pengelolaan SDM yang handal dan berkualitas menurut David Osborne salah satu upaya mengeksplor strategi organisasi dalam mencapai tujuan adalahdengan tehnik analisis SWOT (Strenght, Weeknesses, Opportunities dan Threats). ${ }^{2}$

Konsep dasar analisis SWOTsebenarnya bertitik tolak dari pemikiran sederhana. SDM yang mengetahui kekuatan dan peluang serta kelemahandiri sendiri sekaligus mengenal ancaman yang terjadi, maka dialah yang menjadi pemenang. SDM yang mampu memadukan atau menciptakan kekuatan dengan peluang dan memperkecil kelemahan dan ancaman maka dialah yang menjadi pemenang. Jelasnya output dari analisis SWOT adalah diketahuinya factor-faktor kunci keberhasilan organisasi sehingga diperoleh langkah-langkah strategi mencapai keberhasilan. Rangkuti, Freddy menjelaskanlangkah perumusan SWOT adalah sebagai berikut; 1) Identifikasi faktor internal dan eksternal dilakukan dengan tehnik brainstorming atau curah pendapat; 2) Komparasi urgensi faktor internal dan eksternal untuk mengetahui faktor yang menjadi kebutuhan pencapaian tujuan dan sasaran, berikutnya ditindaklanjuti dengan melakukan komparasi antar faktor, 3) Peta posisi kekuatan organisasi total dan nilai bobot semua strength, weakness- es, opportunities dan threaths dapat diposisikan peta kekuatan organisasi, 4) Formulasi Strategi berdasarkan hasil analisis SWOT. Untuk mengetahui kekuatan dan peluang serta kelemahan dan ancaman melalui evaluasi, sesuai Abudin Nata, evaluasi merupakan menilai hasil akhir dari proses kegiatan. ${ }^{4}$ Oemar Hamalik mnyebutkan evaluasi sebagai suatu penaksiran terhadap kemajuan, pertumbuhan dan perkembangan. ${ }^{5}$ Arifin menyebutkan evaluasi merupakan cara atau tehnik penilaian. ${ }^{6}$

Hasil analisis evaluasi proses implementasi program tridarma PTdalam upaya pengembangan SDM pada IAIN Bengkulu. Menunjukkan bahwa terdapat kekuataan seperti memiliki 262 pegawai, 150 dosen dan 112 pegawai. ${ }^{7} 108$ Dosen kualifikasi pendidikan S2 dan 42 dosen kualifikasi pendidikan S3.Rincianpangkat para dosen adalah asisten ahli berjumlah 56 dosen, lektor berjumlah 46 dosen, lektor kepala berjumlah 51 dosen, dan guru besar 2 orang dosen. ${ }^{8}$

Sedangkan kelemahan seperti masih terdapat gelar yang tidak relevan dengan bidang ilmu yang diampunya, ratio antara dosen dengan mahasiswa masih belum seimbang yaitu 1 berbanding 40, dan kemampuan tenaga pengajar yang rendah dalam menyelesaikan tugas, dan sumberdaya terbatas dan kapasitasnya kurang, seperti jumlah dosen 150 baru 55 dosen terindeks sinta. ${ }^{9}$ Dan guru besarhanya ada 2 (dua) yang disahkan sebelum tahun 2014,keterangan kepala LPPM, dosen belum optimal dalam melakukan penelitian dan publikasi ilmiah, ${ }^{10}$ sehingga mengakibatkan lambatnya proses kenaikan pangkat dan penambahan guru besar. Disisi lain kebutuhan, keinginan,dan harapan pelanggan sebagai peluangIAIN Bengkulu memiliki 22 jurnal baik cetak maupun on line. ${ }^{11}$

Merupakaninput dan harus diolah dan mendatangkan suatu keuntungan atau manfaat besar bagi dosen bagian penelitian dan publikasi ilmiah untuk pemenuhan perhitungan angka kredit 
60

NUANSA Vol. XII, No. 1, Juni 2019

(PAK) kenaikan pangkat. Sebaliknya hasil evaluasi menunjukkan IAIN Bengkulu mendapatkan hambatan pada komitmen dan anggaranuntuk program pemanfaatan peran tridarma PT secara efektif, sehingga tidak terkesan manajemen pelayanan tridarma PT seolah terabaikan. ${ }^{12}$

Untuk lebih optimal pencapaian peran program tridarma PT pada IAIN Bengkulu perlu penambahan anggaran, sehingga para tenaga pengajar dalam menjalankan peran fungsinya dapat lebih efektif untuk meningkatkan prestasi peran tridarma PT dan dapat memperbaharui dan melengkapi sarana prasarana yang modern mendukung proses belajar mengajar berkelas dunia dan IAIN Bengulu semakin kuat memperoleh international recognition, sehingga keberadaan IAIN Bengkulu memperoleh pengakuan dari masyarakat menuju world class university.

Berdasarkan hal diatas, paper menjelaskan evaluasi program tridarma PTdalam upaya pengembangan sumberdaya manusia menuju world class universitysebagai PTKIN di Bengkulu. Makalah ini membahas latar belakang (konteks) program tridarma PT,masukan (perencanaan) program tridarma perguruan tinggi, implementasi (proses) program tridarma perguruan tinggi, dan capaian (produk) program tridarma PT dalam upaya pengembangan SDM menuju world class University.

\section{Latar Belakang (Konteks) Program Tridarma Perguruan Tinggi dal UpayaPengembangan SDM.}

Perguruan Tinggi (PT)sebagaiinstitusi publik memberikan layanan pada masyarakat bidang pendidikanyang memiliki peran sebagai tridarma PT. Pendidikan, penelitian dan pengabdian pada masyarakat mempunyai andil penting dalam renking Webometrics sebagaipengakuan Internasional berbasis web dan perkembangan ilmu pengetahuan dalam peningkatan SDM yang berpengetahuan, berkeahlian, berkompeten, dan terampil. ${ }^{13}$

Ada beberapa aspek yang perlu dievaluasi terkait latar belakang program tridarma perguruan tinggi yaitu: kebutuhan, permasalahan dan tujuan. Hasilevaluasi program dari masing-masing aspek adalah sebagai berikut:

Pertama, Program tridarma perguruan tinggi dibuat didasarkan atas kebutuhan untuk kepentingan perguruan tinggi (IAIN) yaitu; dalam rangka menjadikan tenaga pengajar (dosen) yang professional dan kompeten untuk mendukung tugasnya dalam peningkatan kualitas pendidikan nasional Indonesia. IAIN Bengkulu sangat membutuhkan tenaga pengajar yang berkualitas untuk mencetak genersi penerus alumni yang berkualitas yang siap mengisi lapangan kerja di masyarakatdaam upaya mendukung peningkatan mutu pendidikan nasioal. Program tridarma perguruan tinggi pada IAIN Bengkulu disusun dan dilaksanakan berdasarkan visi, misi perguruan tinggi. Hal ini ditunjukkan seperti adanya kegiatan-kegiatan yang selalu diarahkan kepada pengembangan SDM berbasis kewirausahaan. Pengembangan SDM berbasis kewirausahaan untuk memberikan bekal awal bagi para alumni yang mandiri. Dengan kegiatan tersebut diharapkan para alumni mampu menjalin komunikasi, kerja sama dan membangun kebersamaan yang tinggi sebagai elemen bangsa, guna membawa Indonesia yang aman, adil, makmur dan sejahtera sesuai cita-cita bangsa dan negara Indonesia.

Kedua, Permalahan yang muncul menjadi pendorong dirumuskannya suatu program keberadaan program tridarma perguruan tinggi memang dibutuhkan untuk mewujudkan SDM yang berkualitas, khususnya untuk menyediakan para alumni yang professional dan kompeten pada bidangnya masing-masing, sehingga ketika bekerja akan memiliki pengetahuan dan keterampilan yang memadai. IAIN Bengkulu sebagai lembaga pendidikan bertugas mengefektifkan 
Khairiah | Evaluasi Program Tridarma Perguruan Tinggi

peran tridarma perguruan tinggi kepada tenaga pengajar untuk meningkatkan keterampilan dan kompetensinya dengan program yang direncanakan dengan baik dan disusun secara integratif sehingga dapat meningkatkan kualitas para alumni IAIN Bengkulu. Terkait dengan latar belakang program yang berkenaan masalah penguasaan teknologi. Untuk dapat menguasai teknologi yang dibutuhkan IAIN Bengkulu, maka dibutuhkan adanya pendidikan khusus dan focus, sehingga memerlukan adanya model pendidikan yang sistematis.

Oleh karena itu IAIN Bengkulu dimaksudkan menjadi wadah pendidikan untuk memperkuat penguasaan yang diikuti adalah mewajibkan setiap mahasiswa mampu mengoperasi Iptek dibuktikan dengan sertifikat computer, karena IAIN Bengkulu telah menerapkan sistem informasi akademik (SIAKAD), system verifikasi ijazah online secara elektronik (SIVIL), penomoran ijazah nasional(PIN), Education Management Information System (EMIS), Pangkalan Data Pendidikan Tinggi (PDPT), dan E-kampus. Semua layanan telah menggunakan aplikasi online.Permasalah selanjutnya yang melatarbelakangi program peran tridarma perguruan tinggi IAIN Bengkulu adalah system pendidikan, penelitian dan pengabdian masyarakat internal yang kurang mampu memenuhi tuntutan kompetensi yang dibutuhkan. Dari hasil evaluasi diperoleh keterangan, jika hanya mengandalkan pendidikan dari internal, maka IAIN Bengkulu masih kurang untuk memfungsikan peran tridarma perguruan tinggi pada IAIN Bengkulu yang berkualitas, sehingga membutuhkan pendidikan sejak dini yang khusus penguasaan system aplikasi online. Program tridarma perguruan tinggi diperlukan untuk membangun SDM yang berkualitas, karena untuk menciptakan SDM yang berkualitas dibutuhkan adanya system yang terbaik untuk memberikan bekal keterampilan dan pengetahuan dalam memerankan tridarma perguruan tinggi.
Ketiga, Hasil evaluasi dalam penelitian ini menunjukkan bahwa program tridarma perguruan tinggi IAIN Bengkulu tujuannya sejalan dengan usaha mewujudkan world class University, dan Webometrics sebagai dasar penilaian rating IAIN Bengkulupada layanan berbasis web dan pengakuan internasional. ${ }^{14}$

Rektor mendukung penuh proses program google Scholar index dalam program Open Journal System (OJS). ${ }^{15}$ Upaya peningkatan reputasi akademik menunjang peringkat webometrics,menuju terwujudnya World class university hanya dapat diwujudkan jika perguruan tinggi memiliki SDM yang kuat, berkualitas dan professional dan didukung oleh teknologi memadai. IAIN Bengkulu dinilai sebagai salah satu instrument utama untuk mewujudkan SDM yang berkualitas dan professional dalam upaya mewujudkan perguruan tinggi IAIN Bengkulu yang berkelas dunia.posisi webometricTahun 2018 IAIN Bengkulu peringkat nasional $558^{16} \mathrm{dan}$ peringkat dunia $15230 .{ }^{17}$

Dan Januari 2019 posisiwebometricIAIN Bengkulu peringkat nasional 125 dan peringkat dunia $6561 .{ }^{18}$

Selain webometric, Setiap tahun Rektor menyiapkan anggaran untuk penelitian, pengabdian, dan publikasi ilmiah guna target webometric dan internasionalisasi web kampus, untuk perbaikan rangking webometrics dan internasinalisasi web kampus. Hal ini didukung dengan anggaran Tahun 2017, sebesar Rp. 2.993,305,000,Tahun 2018 sebesar 2.200.000.000,- ${ }^{19}$

\footnotetext{
${ }^{9}$ http://mail.google.com

${ }^{10}$ Khairiah, Sirajuddin. The Effects of University Leadership Manage ment: Efforts to Improve the Education Quality of State Institute for Islamic Studies (IAIN) of Bengkulu, Jurnal Pendidikan Islam Yogyakarta/Volume $7 /$ Nomor 2/ Januari 2019/ISSN (P) 2301-9166/ ISSN (online) 2356-3877/ h. 239266.

${ }^{11}$ Khairiah, Sirajuddin. Ibid. h. 239-266.

${ }^{12}$ Khairiah, Pengaruh Struktur Organisasi (Organizational Structure), Kepuasan Kerja (Job Satisfaction) Terhadap Komitmen Organisasi (Organizational Commitmen) Pada Institut Agama Islam Negeri Bengkulu, Jurnal Studi Islam dan Kemasyarakatan, Nuansa/Vol.X/No.1/hal.1-83/ Juni2017/ ISSN:2086-4493. H. 51

${ }^{13}$ Khairiah, Sirajuddin. Ibid. h. 239-266

${ }^{14}$ Nur Syam, Dari Bilik Birokrasi, Esai Agma, Pendidikan dan Birokrasi, Kementerian Agama, (Jakarta, 2014), h.150-151
} 
62

NUANSA Vol. XII, No. 1, Juni 2019

untuk menumbuhkan kesadaran civitas akademika dalam peran tridarma perguruan tinggi pada website terutama OJS. Publikasi dalam web adalah salah satu pola pendongkrak nilai visitasi web IAIN Bengkulu sehingga peningkatan rating webometrics pada posisi sekarang menuju World class University.

\section{Masukan (Perencanaan) Program Tridarma Perguruan Tinggi dal Upaya Pengembangan SDM.}

Keberhasilan suatu program membutuhkan adanya masukan atau perencanaan yang memadai. Dalam konteks program tridarma perguruan tinggi IAIN Bengkulu, maka masukan yang dibutuhkan yaitu SDM, anggaran, danfasilitas. Hasil evaluasi terhadap keempat factor tersebut dijelaskan sebagai berikut:

Pertama, Hasil evaluasi sumberdaya manusia menunjukkan bahwa kompetensi tenaga pengajar pada IAIN Bengkulu cukup baik, karena setiap tenaga pengajar sudah memiliki kompetensi sesuai bidang masing-masing. Kompetensinya terus ditingkatkan baik dilakukan oleh tenaga pengajar maupun dukungan manajemen penyelenggara lembaga untuk memberikan kesempatan menempuh pendidikan S1, S2 dan S3 serta pendidikan dan latihan, kursus-kursus. Setiap rekrutmen tenaga pengajar harus dilakukan seleksi atau tes kelayakan, sebelum menjadi tenaga pengajar.

Aspek SDM tenaga pengajar juga dilihat aspek jumlahnya, karena jumlah rasio antara tenaga pengajar dengan mahasiswa juga mempengaruhi keberhasilan IAIN dalam melaksanakan proses belajar mengajar. Hasil evaluasi menunjukkan bahwa jumlah tenaga pengajar cukup memadai dan selama ini kekurangan tenaga pengajar ditutupi oleh dosen tetap non PNS dan dosen luar biasa (DLB), sehingga tenaga pengajar sudah disesuaikan dengan kebutuhan.

Kualifikasi tenaga pengajar harus tepat. Hasil evaluasi menunjukkan mayoritas tenaga pengajar sudah sesuai, karena setiap tenaga pengajar harus disesuaikan dengan kualifikasi yang dibutuhkan. Semua tenaga pengajar sudah berkualifikasi sesuai persyaratan Dikti bahwa tenaga pengajar S1/D4 minimal S2 kurang lebih $40 \%$. Berdasarkan latar belakang pendidikan umumnya tingkat kesesuaian $100 \%$. SDM dari staff juga merupakan factor penentu keberhasilan IAIN Bengkulu dalam mewujudkan tujuannya. Hasil evaluasi menunjukkan bahwa kompetensi staff IAIN Bengkulu memiliki kompetensi yang cukup baik dan selama ini terus dilakukan usaha untuk meningkatkan kompetensinya melalui upaya pendidikan dan pelatihan. Para staff IAIN Bengkulu umumnya dapat melaksanakan tugas-tugas administrasi dengan baik dan jarang melakukan kesalahan. Demikian pula jumlahnya memadai namun belum sesuai kebutuhan, sehingga untuk mencukupi dalam melaksanakan tugas-tugas administrasi dibantu oleh tenaga honorer yaitu pramubakti untuk mewujudkan tata kelola perguruan tinggi yang baik berkelas dunia.

Kedua, Hasil evaluasi angaran menunjukkan bahwa anggaran yang digunakan untuk melaksanakan program tridarma perguruan tinggi pada IAIN Bengkulu berasal dari APBN. Dan Anggaran yang dialokasikan untuk penyelenggaraan program tridarma perguruan tinggi sudah relative mencukupi kebutuhannya, karena sudah direncanakan dengan baik, dalam prakteknya pada IAIN Bengkulu secara umum anggaran dibagi beberapa kelompok yaitu biaya operasional dan belanja modal serta belanja barang non operasional.

Ketiga, Hasil evaluasi fasilitas menunjukkan bahwa saat ini IAIN Bengkulu sudah memiliki ruang kelas yang cukup memadai dalam melangsungkan proses belajar mengajar. Ruang kelas sudah cukup nyaman untuk proses belajar mengajar, kondisi meja dan kursi memadai, ruang ber AC dan dilengkapi media pembelajaran 
Khairiah | Evaluasi Program Tridarma Perguruan Tinggi

yang atraktif. Dukungan teknologi informasi pada IAIN Bengkulu cukup baik dan dapat memperlancar proses belajar mengajar dan memudahkan memperoleh informasi dan pengetahuan. Hal yang masih perlu ditingkatkn terutama dari segi kecepatan akses internet dan pengenalan teknologi informasi untuk kualitas dan peringkat webometricIAIN Bengkulu. Selanjutnya untuk sarana prasarana kondisinya cukup memadai, sehingga mendukung untuk kegiatan proses belajar mengajar. Untuk media pembelajaran menunjukkan bahwa saat ini cukup memadai, sehingga membantu dalam proses belajar mengajar. Kemudian sarana prasarana perpustakaan kondisinya sangat memadai untuk mencari referensi-referensi yang diperlukan untuk menuju kelas dunia.

\section{Implementasi (Proses) Program Tridarma Perguruan Tinggi IAIN Bengkulu.}

Implementasi program merupakan tahapan paling penting dan menentukan keberhasilan program dalam mencapai tujuan. Tahapan ini harus dilakukan dengan sungguh-sungguh supaya kegiatan yang dilakukan sesuai perencanaan awal. Sesuai Stufflebeam dan Shinkfield model evaluasi CIPP merupakan tahapan proses pelaksanaan program. ${ }^{20}$ Aspek-aspekyang terkait dengan implementasi yaitu ketepatan waktu, penerapan metode, monitoring dan evaluasi, pengembangan SDM, rekrutmen tenaga pengajar dan staff dan pelayanan terhadap mahasiswa. Hasil evaluasi untuk masing-masing aspek sebagai berikut:

\footnotetext{
2018

${ }^{15}$ Data Pusat Komputer Institut Agama Islam Negeri Bengkulu Tahun ${ }^{16} \mathrm{http} / / /$ www.webometrics.info/en/search/Rangkings/bengkulu\%3 Apeis

${ }^{17} \mathrm{http}: / /$ www.webometrics.info/en/search/Rangkings/Bengkulu rics 2019

${ }^{18} \mathrm{http} / / /$ sevima.com Universitas Terbaik di Indonesia Versi Webomet-

${ }^{19}$ Data Bagian Perencanaan, Keuangan dan Akuntansi Biro Administrasi Umum Akademik dan Kemahasiswaan (AUAK) Institut Agama Islam Negeri (IAIN) Bengkulu Tahun 2018

${ }^{20}$ Stufflebeam, Daniel L. dan Anthony J. Shinkfield. Evaluation Theory, Models and Applications. (San Francisco: Jossey-Bass, 2007), h. 327
}

Pertama,Hasil evaluasi ketepatan waktu, menunjukkan bahwa penyelenggaraan proses belajar mengajar pada 4 (empat) Fakultas dan satu Program Pascasarjananyaitu Fakultas Syariah, Fakultas Tarbiyah dan Tadris, Fakultas Ushuluddin Adab dan Dakwah, serta Program PascasarjanaIAIN Bengkulu selama ini sudah dilakukan secara tepat waktu sesuai kalender akademik yang sudah dibuat. Sistem akademik IAIN Bengkulu setiap tahun membuat kalender akademik yang ditetapkan melalui keputusan Rektor IAIN Bengkulu yang dirinci setiap bulan, meliputi kegiatan perkuliahan, kegiatan latihan, kegiatan evaluasi, kegiatan integrative dan penyelesaian SKS dilakukan secara tepat waktu. Untuk ketepatan waktu pelaksanaan evaluasi belajar seperti absensi/keaktifan, ujian tengah sementer (UTS), ujian akhir semester (UAS) sudah dilaksanakan secara tepat waktu. Hanya saja kadang-kadang waktu pelaksanaannya berubah sehingga, jika ada kegiatan di luar rencana, atau jika ada kegiatan yang waktu pelaksanaannya berubah, sehingga terpaksa harus diikuti. Sementara proses manajemen akademik dalam program studi meliputi lama studi rata-rata di IAINBengkulu selama 4 tahun. Program studi Fakultas Syariah dengan masa studi 4,1 tahun dengan IPK rata-rata 3,35, Fakultas Ushuluddin Adab dan Dakwah 4,1 tahun dengan IPK 3,33, Fakultas Tarbiyah dan Tadris 4,2 tahun dengan IPK 3,29, Fakultas Ekonomi dan Bisnis Islam 4,1 tahun dengan IPK 3,35, dan Program Pasca Sarjana 2 tahun dengan IPK 3,49 adalah wujud ratarata lulusan dari tiga tahun terakhir. ${ }^{21}$

Penyelenggaraan proses manajemen akademik diwujudkan dalam Jumlah penelitian IAINBengkulu. Data selama 3 tahun terakhir dari penelitian individu adalah Tahun 2013 ada 25 judul penelitian dari 25 dosen, Tahun 2014 ada 34 Judul dari 34 dosen, dan Tahun 2015 ada 45 Judul penelitian dari 45 Dosen. Data Jumlah penelitian kelompok IAIN Bengkulu pada 3 tahun terakhir 
64

NUANSA Vol. XII, No. 1, Juni 2019

adalah Tahun 2013 ada 10 kelompok penelitian, Tahun 2014 ada 14 kelompok penelitian, dan Tahun 2015 terdapat 7 kelompok penelitian. Dan penyelenggaraan penelitian pada IAIN Bengkulu selama ini sudah dilakukan secara tepat waktu sesuai jadwal yang telah dibuat Lembaga penelitian dan pengabdian masyarakat (LPPM), setiap tahun membuat usulan melalui sistem Penelitian dan Pengabdian Masyarakat (LITAPDIMAS), dan sudah dilaksanakan tepat waktu dibuktikan dengan laporan yang disampaikan kepada Rektor IAIN Bengkulu Up. Keuangan dalam satu tahun berjalan. ${ }^{22}$

Kedua, Hasil evaluasi penerapan metode pembejaran pada pada 4 (empat) Fakultas dan satu Program Pascasarjanan yaitu Fakultas Syariah, Fakultas Tarbiyah dan Tadris, Fakultas Ushuluddin Adab dan Dakwah, serta Program Pascasarjana IAIN Bengkulu menunjukkan bahwa selama ini penerapan metode pembelajaran oleh para tenaga pengajar cukup menarik, tidak membosankan dan cukup bervariatif sesuai dengan tema dan materi yang diajarkan. Metode pembelajaran yang digunakan oleh tenaga pengajar seperti praktek langsung atau magang, studi kasus (latihan penelitian dan publikasi imiah), ceramah, diskusi (hasil diskusi dipublikasi pada jurnal ilmiah). Pemilihan metode umumnya disesuaikan dengan topik pembelajarannya. Metode pembelajaran tersebut untuk berlangsungnya proses belajar mengajar dan bimbingan pengasuh yang bersifat merangsang kemampuan berfikir secara integral dan mendorong motivasi belajar mandiri.

Ketiga, Hasil evaluasi monitoring dan evaluasi pembelajaran, menunjukkan bahwa monitoring dan evaluasi pembelajaran dilakukan terhadap mahasiswa selama ini berjalan cukup baik. Monitoring dan evaluasi dilakukan melalui tes atau ujian utuk melihat kemampuan para mahasiswa, seperti mental kepribadian, karakter dan tingkat intelektualitas. Untuk evaluasi secara umum, dilakukan secara internal dengan membuat laporan tahunan untuk melihat capaian-capaian kinerja sebagaimana yang telah direncanakan. Terkait manajemen pembelajaran pada 4 (empat) Fakultas dan satu Program Pascasarjanan yaitu Fakultas Syariah, Fakultas Tarbiyah dan Tadris, Fakultas Ushuluddin Adab dan Dakwah, serta Program Pascasarjana IAIN Bengkulu menunjukkan bahwaharus memperbaiki $\mathrm{SDM}^{23}$ walaupun dalam penelitian Kuantitatif menunjukkan kualitas pegawai IAIN Bengkulu 88,78\% sangat baik. ${ }^{24}$ Evaluasi pembelajaran dapat dilihat dalam 3 komponen utama dalam penilaiaan totalitas layanan. Tiga tersebut adalah input layanan, proses layanan dan output layanan. IAIN Bengkulu saling sinergi dengan kebutuhan sehingga ada pola kecocokan antara kebutuan dan layanan pengguna lembaga pendidikan. ${ }^{25}$

Untuk kegiatan pengawasan selama ini telah dilakukan dengan baik dari pihak internal sendiri yaitu Lembaga Penjaminan Mutu (LP) dalam pemenuhan Beban Kerja Dosen (BKD) on line dan Satuan Pengawasan Internal (SPI) dan pengawasan dari inspektorat jenderal Kementerian Agama RI.

Keempat, Hasil evaluasi pengembangan SDM, sesuai Noe et al. pengembangan SDM merupakan kombinasi dari pendidikan formal, pengalaman kerja, hubungan kerja, penilaian kepribadian dan kemampuan membantu pegawai mempersiapkan masa depan kariernya. ${ }^{26}$

Hasilnya menunjukkan bahwa IAIN Bengkulu memiliki 108 dosen kualifikasi pendidikan S2 dan 42 dosen kualifikasi pendidikan

${ }^{21}$ Data Bagian Akademik Biro Administrasi Umum Akademik dan Kemahasiswaan Tahun 2018

${ }^{22}$ Data Bagian Akademik Biro Administrasi Umum Akademik dan Kemahasiswaan Tahun 2018. Dan Data Lembaga penelitian dan pengabdian masyarakat (LPPM) IAIN Bengkulu Tahun 2018

${ }^{23}$ Noe, RA, et al., Manajemen Sumber Daya Manusia, Edisi kesepuluh, (Jakarta: Indeks Pendidikan Nasional, 2007), h. 36

${ }^{24}$ Khairiah, Penelitian Mandiri, Pengaruh Manajemen, Kepemimpinan Terhadap Peningkatan Mutu Pendidikan Tinggi Islam Pada Institut Agama Islam Negeri, Bengkulu, Tahun 2017 
Khairiah | Evaluasi Program Tridarma Perguruan Tinggi ef

S3.Rincianpangkat para dosen adalah asisten ahli berjumlah 56 dosen, lektor berjumlah 46 dosen, lektor kepala berjumlah 51 dosen, dan guru besar 2 orang dosen. ${ }^{27}$

Telah dilakukan berbagai upaya pengembangan SDM seperti diikutkan kursus, mengikutkan pelatihan sesuai bidang keilmuan, bimbingan dan pembinaan dari unsur pimpinan untuk meningkatkan pengetahuan dan keterampilannya. pelaksanaan Pertemuan Internasional IAIN Bengkulu dengan Universitas Luar Negeri. IAIN Bengkulu kerjasama dengan Luar Negeri tercatat 2015 dengan 5 negara 4 di Asia 1 di Eropa, 2016 dengan 10 negara dengan 9 dari Asia 1 dari Australia, 2017 dengan 3 negara 2 Asia 1 Eropa. 2018 baru ada 2 semua dari Asia. Selama 4 tahun, IAIN Bengkulu dalam kerjasama yang telah ditandatangani dalam MOU melakukan 4 kegiatan berupa konfrensi Internasional, Short cours, Pratikum, dan pengabdian. Konfrensi dilaksanakan 17 kali dengan Universitas negara-negara Asia dan negara Eropa. ${ }^{28}$

Usaha lain yaitu dengan melakukan kerjasama dengan perguruan tinggi dalam dan luar negeri, untuk mengembangkan tenaga pengajar pada IAIN Bengkulu yaitu dengan memberikan biasiswa S2 dan S3. Konfren pada IAIN Bengkulu telah dihadiri olehProf. Dr. H. Nadirsyah Hosen LLMMA.DariUniversitasWollongoAustralia, Prof Dr Azharuddin Sahil, Dr H Abdul Halim Bin H Ismail Ibnu Syaid Dinaa Albar dari USM Malaysia, Datok Abdul Manap dari MMJ Malaysia, Prof. Dr. Saudah dari UTM Malaysia, dan Prof Dr Mulyadi Kartanegara MA dari Universitas Brunei Darussalam. Beberapa nama konfrensi Internasional yang diikuti oleh IAIN Bengkulu International Conference on Recent Advanced in Mathematics Biology Analysis and Application (ICMBAA), International Conference on Numerical Optimization and Operation Research (ICNOOR), International Conference Technology (ICTEL), International Teaching Practicum (ITP), Inter- national Conference on Science an Tecnology for Sustainability(ICOSTECHS), Seminar on Science and Technology (SNT), International Conference on Islamic Education (ICIE), International Conference on Sosial Sciences and Humanities II (ICOSAH II), International Conference on Sosial Science (ICESS), dan International Conference on Librang and Infornation Technology (ICOLIT). Untuk pengembangan yang dilakukan terhadap tenaga administrasi pada prinsipnya sama dengan pengembangan yang dilakukan terhadap tenaga pengajar. Pengembangan yang dilakukan seperti kursus, pendidikan dan pelatihan, pembinaan secara berjenjang dan memberikan kesempatan untuk melanjutkan pendidikan S1, S2 dan S3. ${ }^{29}$

Kelima, Hasil evaluasi rekrutmen tenaga pengajar dan tenaga administrasi, menunjukkan bahwa selama ini rekrutmen yang dilakukan oleh IAIN Bengkulu mengikuti kebijakan kementerian agama RI, dan Menteri Pendayagunaan Aparatur Negara (Menpan), sehingga hanya menerima personil yang ditempatkan pada IAIN Bengkulu. Dari personil yang masuk, hanya yang mempunyai kualifikasi pendidikan dan mengajar yang dijadikan tenaga pengajar. Penempatan biasanya sudah disesuaikan dengan kualifikasi dan keilmuan masing-masing untuk mengajar. Kualifikasi untuk menjadi tenaga pengajar diusahakan lulusan S2 atau S3sesuai dengan mata kuliah yang diampu. Dalam proses rekrutmen telah dilakukan secara tranparan berdasarkan kebutuhan dan kompetensinya, kebutuhan dosen diawali melalui pengajuan dari prodi, dan dekan fakultas.

Keenam, Hasil evaluasi pelayanan menunjukkan bahwa tenaga pengajar dan tenaga ad-

${ }^{25}$ Hadis Abdul dan Nurhayati, Manajemen Mutu Pendidikan Islam, (Bandung: Penerbit Alfabeta, 2012), h. 2

${ }^{26}$ Noe, Raymond A., John R. Hollenbeck, Barry Gerhart, dan Patrick M. Wright. Fundamentals Of Human Resource Managemen. (New York; The McGraw-Hill Companies, Inc., 2011),h. 259.

${ }^{27}$ Data Bagian Kepegawaian Biro Administrasi Umum Akademik dan Kemahasiswaan (AUAK) IAIN Bengkulu Tahun 2018

${ }^{28}$ Data Sub Bagian Kerjasa Biro AUAK IAIN Bengkulu Tahun 2018 
66 窟

NUANSA Vol. XII, No. 1, Juni 2019

ministrasi pada IAIN Bengkulu selama ini telah memberikan respon yang cepat dalam memberikan pelayanan kepada para mahasiswa. Tenaga pengajar telah berupaya melakukan pelayanan kepada mahasiswa dengan cepat, demikian pula tenaga administrasi cepat memberikan respon ketika mahasiswa memerlukan layanan administrasi. Tenaga pengajar dan tenaga administrasi pada IAIN Bengkulu dinilai memiliki kepedulian yang cukup untuk membantu memberikan pelayanan prima kepada pelaanggan.Tenaga pengajar dan tenaga administrasi pada IAIN Bengkulu, senantiasa menunjukkan profesionalitas dan kompetensinya dalam melaksanakan tugastugasnya dan juga saat melayani mahasiswa. Hasil penelitian kuantitatif menunjukkan kualitas pegawai IAIN Bengkulu 88,78\% yang berarti baik. ${ }^{30}$

Hasil tersebut menggambarkan bahwa secara umum untuk aspek implementasi program terutama aspek ketepatan waktu, metode pembelajaran dan layanan tergolong baik menuju perguruan tinggi kelas dunia.

\section{Capaian (Produk) Program Tridarma Pergu- ruan Tinggi IAIN Bengkulu.}

Capaian yang diharapkan dari program tridarma perguruan tinggi pada IAIN Bengkulu untuk mendukung terwujudnya world class University.Untuk mengetahui keberhasilan program world class University, maka dibutuhkan evaluasi, sesuai Stufflebeam dan Shinkfield, model evaluasi CIPP masudnya evaluasi produk berarti mengidentifikasi dan menilai hasil, baik yang dikehendaki maupun yang tidak, focus pada pencapaian hasil organisasi. Evaluasi produk juga terkait dampak, efektivitas, keberlanjutan dan kemudahan. ${ }^{31}$

Proses manajemen mutu dapat dilihat dalam 3 komponen utama dalam penilaiaan totalitas layanan. Tiga tersebut adalah input layanan, proses layanan dan output layanan. Mutu IAIN
Bengkulu saling sinergi dengan kebutuhan sehingga ada pola kecocokan antara kebutuan dan layanan pengguna lembaga pendidikan. Dengan demikian mutu merupakan ukuran terkait kepuasan pengguna layanan pendidikan tinggi. Para pengguna ini adalah via kampus dan via luar kampus. Via kampus adalah mahasiswa, dosen dan pegawai kampus. Via luar kampus adalah organisasi mahasiswa (ormawa), masyarakat, instansi terkait, dan lembaga induk pangkalan data perguruan tinggi.

Mutu pencapaian kesuksesan IAIN Bengkulu meliputi perkembangan kebebasan akademik dalam kegiatan pengajaran, penelitian, dan publikasi ilmiah dengan aturan yang ada. Profesor bebas menentukan isi kuliah dan menerbitkan hasil penelitian tanpa meminta persetujuan stakekholder IAIN Bengkulu. IAIN Bengkulu telah menciptakan suasana akademik yang kondusif dengan kebebasan akademik untuk lembaga, pusat dan unit kerja IAIN Bengkulu sebagai wahana pembelajaran dengan ciri khas pengelola. Keterbukaan IAIN Bengkulu adalah motivasi dan komunikasi dalam peredaman pola arogansi akademik dalam pencapaiaan nilai toleransi sebagai lingkungan akademik kondusif. Keterbukaan menciptakan kerjasama staf dan Dosen sebagai Team work dalam upaya pengembangan SDM IAIN Bengkulu.

Tolak ukur capaian kinerja SDM melalui system informasi penelitian berbasis web yaitu sinta yang digagas oleh Kemenristek Dikti pada Tahun 2016. Konten Sinta yang telah dipublikasikan secara elektronik memiliki profil atau google schol-

${ }^{29} \mathrm{Khairiah}$, Sirajuddin. The Effects of University Leadership Management: Efforts to Improve the Education Quality of State Institute for Islamic Studies (IAIN) of Bengkulu, Jurnal Pendidikan Islam Yogyakarta/Volume 7/ Nomor 2/ Januari 2019/ISSN (P) 2301-9166/ ISSN (online) 2356-3877/ h. 239266.

${ }^{30}$ Khairiah, Penelitian Mandiri, Pengaruh Manajemen, Kepemimpinan Terhadap Peningkatan Mutu Pendidikan Tinggi Islam Pada Institut Agama Islam Negeri, Bengkulu, Tahun 2017

${ }^{31}$ Stufflebeam, Daniel L. dan Anthony I. Shinkfield. Evaluation Theory, Models and Applications. (San Francisco: Jossey-Bass, 2007), h. 327

${ }^{32}$ Hadis Abdul dan Nurhayati, Manajemen Mutu Pendidikan Islam, (Bandung: Penerbit Alfabeta), h. 2 
ar dan pratinjau Scopus berisi sejumlah kutipan, indeks-h, indeks i-10, prosiding makalah, buku, paten peneliti, dan profil penulis google scholar. $^{33}$ Sedangkan dosen terindeks sinta sebanyak 55 orang. ${ }^{34}$

Capaianmutu Akademik SDM IAIN Bengkulu didukung dari Jumlah dosen tamu. Tahun 2014, Prof. Dr. M. H. Aslam Islahi dari Jawaharlal Nehru University India selama 3 bulan, berada di IAIN Bengkulu. IAIN Bengkulu melakukan MOU pada bidang akademik dalam program dosen tamu. Dosen tamu bekerja dalam proses belajar mengajar, penelitian, narasumber seminar, dan reviewer jurnal. Hal ini membantu Jurnal Madania dalam proses Publikasi, dalam proses pengembangan SDM IAIN Bengkulu untuk Negara pada jenjang internasional. IAIN Bengkulu mengutus narasumber pembicara Internasional dalam tukar informasi. Bentuk fisik dari narasumber adalah karya ilmiah yang publish di jurnal internasional. Hal tersebut upaya mencapai Webometrics sebagai dasar penilaian rating PT menjadi world class University.

\section{Kesimpulan}

1. Program tridarma perguruan tinggi IAIN Bengkulu sesuai dengan latar belakang program yang dilihat berdasarkan aspek kebutuhan membutuhkan ketersediaan personil atau SDM yang berkualitas dalam mewujudkan world class university, permasalahan masih kurangnya kualitas SDM dosen dalam penguasaan teknologi informatika untuk mendukung pendidikan, penelitian dan publikasi ilmiah dan tujuan program tridarma perguruan tinggi untuk mewujudkan world class University;

2. Perencanaan program tridarma perguruan tinggi tenaga pengajar IAIN Bengkulu secara umum dalam kondisi yang cukup baik dan

${ }^{33}$ Web Sinta. http://sinta.ristekdikti.go.id ${ }^{34} \mathrm{http}: / /$ mail.google.com mendukung efektifitas program tridarma perguruan tinggi yang dilihat berdasarkan aspek SDM; telah didukung tenaga pengajar dan staff yang cukup kompeten dan professional dengan jumlah yang memadai dan kualifikasi pendidikan sudah terpenuhi, aspek anggaran; dalam penyelenggaraan tridarma perguruan tinggi memiliki anggara yang cukup untuk pembiayaan pokok tridarma perguruan tinggi, aspek fasilitas secara umum kondisi cukup memadai, baik dan nyaman ruang kelas, didukung teknologi informasi untuk SIAKAD, e-journal, perpustakaan multimedia, e-library, ripositori, e-book.

3. Implementasi atau proses program tridarma perguruan tinggi pada IAIN Bengkulu secara umum sudah dilaksanakan secara baik. Aspek yang dievaluasi terkait implementasi program tridarma perguruan tinggi yaitu ketepatan waktu seperti proses belajar mengajar, evaluasi belajar dan penyelesaian studi serta penelitian dan pengabdian masyarakat sudah dilakukan secara tepat waktu, penerapan metode pembelajaran dengan menerapkan metode pebelajaran kreatif, variatif dan menarik terutama magang, studi kasus, ceramah dan diskusi;aspek pengembangan SDM telah dilakukan seperti kursus, pendidikan dan pelatihan, pembinaan secara berjenjang dan memberikan kesempatan untuk melanjutkan pendidikan S1, S2 dan S3;aspek rekrutmen tenaga pengajar dan staff mengikuti system dari Kementerian Agama RI dan prosesnya dilakukan secara transparan, dan aspek pelayanan menunjukkan bahwa tenaga pengajar dan tenaga administrasi telah memberikan pelayanan prima dan memiliki kepedulian yang cukup tinggi untuk membantu dan bertindak secara professional dalam melaksanakan peran tridarma perguruan tinggi. 
68

4. Hasil dan capaian program tridarma perguruan tinggi meliputi perkembangan kebebasan akademik dalam kegiatan pengajaran, penelitian, dan publikasi ilmiah dengan aturan yang ada. Profesor bebas menentukan isi kuliah dan menerbitkan hasil penelitian tanpa meminta persetujuan stakekholder IAIN Bengkulu. Telah menciptakan suasana akademik yang kondusif dengan kebebasan akademik untuk lembaga, pusat dan unit kerja sebagai wahana pembelajaran dengan ciri khas pengelola. Keterbukaan IAIN Bengkulu adalah motivasi dan komunikasi dalam peredaman pola arogansi akademik dalam pencapaiaan nilai toleransi sebagai lingkungan akademik kondusif. Keterbukaan menciptakan kerjasama staf dan Dosen sebagai Team work dalam upaya pengembangan SDM menujuworld class University.

\section{Daftar Pustaka}

Abudin Nata. 2005. Filsafat Pendidikan Islam, Cetakan ke I, Jakarta: Gaya Media Pratama

Arifin. 2000. Ilmu Pendidikan Islam. Tinjauan Teoritis dan Prkatis Berdasarkan Pendekatan Indisipliner, Jakarta: Bumi Aksara

David Osborne dan Ted Gabler, 1992, ReinventingGovernment- How to Enterpreneurial Spirit is Transforming the Public Sector, Addison Wesley Publishing Inc

Data Pusat Komputer Institut Agama Islam Negeri Bengkulu Tahun 2018

Data Bagian Kepegawaian Biro Administrasi Umum Akademik dan Kemahasiswaan (AUAK) IAIN Bengkulu Tahun 2018

Data Bagian Perencanaan, Keuangan dan Akuntansi Biro Administrasi Umum Akademik dan Kemahasiswaan (AUAK) Institut Agama Islam Negeri (IAIN) Bengkulu Tahun 2018

Data Bagian Akademik Biro Administrasi Umum Akademik dan Kemahasiswaan Tahun 2018
Data Bagian Akademik Biro Administrasi Umum Akademik dan Kemahasiswaan Tahun 2018. Dan Data Lembaga penelitian dan pengabdian masyarakat (LPPM) IAIN Bengkulu Tahun 2018

Data Bagian Kepegawaian Biro Administrasi Umum Akademik dan Kemahasiswaan (AUAK) IAIN Bengkulu Tahun 2018

Data Sub Bagian Kerjasa Biro AUAK IAIN Bengkulu Tahun 2018

Hadis Abdul dan Nurhayati, 2012.Manajemen Mutu Pendidikan Islam, Bandung: Penerbit Alfabeta

http://mail.google.com

http://www.webometrics.info/en/search/Rangkings/bengkulu\%3Apeis

http://www.webometrics.info/en/search/Rangkings/Bengkulu

http://sevima.com Universitas Terbaik di Indonesia Versi Webometrics 2019

J.M. Juran, 1999. "How to Think about Quality" dalam Juran's Quality Handbook,eds. Joseph M. Juran et al. New York: MCGraw-Hill Companies, Inc.

Khairiah, Sirajuddin. The Effects of University Leadership Management: Efforts to Improve the Education Quality of State Institute for Islamic Studies (IAIN) of Bengkulu, Jurnal Pendidikan Islam Yogyakarta/Volume 7/ Nomor 2/ Januari 2019/ISSN (P) 2301-9166/ ISSN (online) 2356-3877/ h. 239-266.

Khairiah, Pengaruh Struktur Organisasi (Organizational Structure), Kepuasan Kerja (Job Satisfaction) Terhadap Komitmen Organisasi (Organizational Commitmen) Pada Institut Agama Islam Negeri Bengkulu, Jurnal Studi Islam dan Kemasyarakatan, Nuansa/ Vol.X/No.1/hal.1-83/ Juni2017/ ISSN:20864493

Khairiah, Penelitian Mandiri, Pengaruh Manajemen, Kepemimpinan Terhadap Peningkatan Mutu Pendidikan Tinggi Islam Pada In- 
Khairiah | Evaluasi Program Tridarma Perguruan Tinggi ef

stitut Agama Islam Negeri, Bengkulu, Tahun 2017

Noe, RA, et al., 2007. Manajemen Sumber Daya Manusia, Edisi kesepuluh, Jakarta: Indeks Pendidikan Nasional.

Noe, Raymond A., John R. Hollenbeck, Barry Gerhart, dan Patrick M. Wright. 2011. Fundamentals of Human Resource Managemen. New York; the McGraw-Hill Companies, Inc.,

Nur Syam, 2014.Dari Bilik Birokrasi, Esai Agma, Pendidikan dan Birokrasi, Kementerian
Agama, Jakarta.

Oemar Hamalik. 1982.Pengajaran Unit. Bandung: Alumni

Rangkuti, Freddy. 1997.Analisis SWOT Teknik Membedah Kasus Bisnis. Jakarta: PT Gramedia Pustaka Utama.

Statistik Institut Agama Islam Negeri (IAIN) Bengkulu Tahun 2017

Stufflebeam, Daniel L. dan Anthony J. Shinkfield. 2007. Evaluation Theory, Models and Applications. San Francisco: Jossey-Bass

Web Sinta. http://sinta.ristekdikti.go.id 